\title{
dosalgarves
}

\section{The creative and cultural tourism ecosystem: A conceptual model}

\section{O ecossistema do turismo cultural e criativo: Proposta de modelo}

\author{
Josefina Salvado \\ Centro Interdisciplinar de História, Culturas e Sociedades (CIDEHUS), Universidade de Évora, \\ Portugal \\ josefina.o.salvado@gmail.com

\section{Ana Maria Ferreira} \\ Centro Interdisciplinar de História, Culturas e Sociedades (CIDEHUS), Universidade de Évora, \\ Portugal \\ amferreira@uevora.pt

\section{Jaime Serra} \\ Centro Interdisciplinar de História, Culturas e Sociedades (CIDEHUS), Universidade de Évora, \\ Portugal \\ jserra@uevora.pt

\section{Noemi Marujo} \\ Centro Interdisciplinar de História, Culturas e Sociedades (CIDEHUS), Universidade de Évora, \\ Portugal \\ noemi@uevora.pt
}

\begin{abstract}
The cultural tourism ecosystem includes a strong creative dimension, to which is added a complex interconnectivity between stakeholders, resources and organizations, which extends across various spatial and sectorial scales. This article seeks to synthesize the cultural and creative tourism "state of the art" as a platform for the construction of a theoretical model guiding creative experience. Proposing a theoretical model, the researchers show a way for a better understanding of the complex creative system, without focusing on details but suggesting a global point of view. The aim is to understand the links between the ideas, determine the importance and relevance of arguments and use to approach the problems in a consistent way. The study is based on a diverse documental analysis and literature review, and aims to suggest a new "Creative Tourism Ecosystem model" which creates and delivers unique tourism experiences (endorsing co-creation of value), integrates responsible and collaborative approaches among all stakeholders (increasing coopetition network strategies) and is a sustainable catalyst for low-population density areas (reinforcing and safeguarding the cultural landscape). As a result, several benchmarks will be presented to illustrate best practices.
\end{abstract}

Keywords: Ecosystem; cultural \& creative tourism; competition; tourism experience model.

\section{Resumo}

O ecossistema do turismo cultural integra uma forte dimensão criativa e agrega uma complexa interconectividade entre stakeholders, recursos, e organizações, que se estendem por diversas escalas espaciais e sectoriais. Este ensaio busca sintetizar o "estado da arte" do turismo cultural e criativo. Propondo um modelo teórico, os pesquisadores mostram um caminho para uma melhor

Dos Algarves: A Multidisciplinary e-Journal, 38-2020.

ISBN 2182-5580 @ ESGHT - University of the Algarve, Portugal.

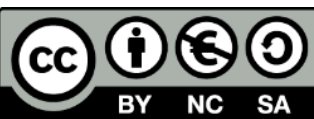

To cite this article: Salvado, J., Ferreira, A. M., Serra, J. \& Marujo, N. (2020). The creative and cultural tourism ecosystem: A conceptual model. Dos Algarves: A Multidisciplinary e-Journal, 38, 59-88. DOI: 10.18089/DAMeJ.2020.38.3 


\begin{abstract}
compreensão do complexo sistema criativo sem se concentrar nos detalhes, mas sugerindo um ponto de vista global. Visa mostrar de um modo sistémico, os links entre as ideias, determinar a importância e a relevância dos argumentos. $O$ trabalho é sustentado por uma análise documental e de literatura diversa, sugerindo um modelo de ‘Ecossistema de Turismo Criativo' que encoraje a criação de uma Oferta singular de experiencias turísticas (promovendo a cocriação de valor), integrando abordagens responsáveis e colaborativas entre todos os stakeholders (estimulando o aumento de redes de coopetição) e que se constitua como um catalisador sustentável dos territórios de baixa densidade (fortalecendo e salvaguardando a paisagem cultural).
\end{abstract}

Palavras-chave: Ecossitema; turismo cultural e criativo; competição; modelo conceptual; experiência turistíca.

\title{
1. Introduction
}

Creative Tourism offers visitors the opportunity to develop their creative potential through active participation in courses and learning experiences, which are characteristic of the holiday destination where they are taken (Richards \& Raymond, 2000: 18).

Tourism is a complex business, described as a system (Leiper, 1979) which possesses complex interconnectivity between its stakeholders and resources. Goeldner and Ritchie (2006) argue that the tourism ecosystem involves organisation networks which extend across numerous scales, industries and different spatial activities, connecting a range of actors who each bring a variety of values, roles, interests, abilities, practices and diverse resources and ideas. Figure 1 illustrates how the work was carried out, based on the concept of ecosystem in the belief that creative tourism has the potential to become a crucial tool in the development of low-population density areas.

McCormack (2011) in Gretzel et al. (2015) describes the concept of ecosystem as a system made up of intelligent, autonomous, and adaptable agents, whose objective is to enable interconnections for collective gain. This theme will be analysed in section 2 - "The Ecosystem of Creative Tourism". Section 3 - Methodology consists of an in-depth literature review (67 scientific articles found in journals from the Scopus database), and focuses on defining the main perspectives towards cultural and creative tourism in low-population density areas. Montalto, Moura, Langedijk and Saisana (2017) consider the cultural and creative sectors to be the range of activities based on cultural and/or artistic values and other forms of creative expression. These include architecture, archives, libraries and museums, handicrafts, the audio-visual (including films, television, video games and multimedia), tangible and intangible heritage, design, festivals, music, literature, performing arts, publishers, radio and visual arts.

Section 4 proposes a theoretical model for the "Cultural and Creative Tourism Ecosystem", supported by the four concepts outlined in Table 1, allowing us to highlight the aggregating variables of cultural and creative tourism and to answer the question "What will the largest challenge be for managers in the cultural and creative tourism ecosystem?". 
Figure 1. Structural model of the work

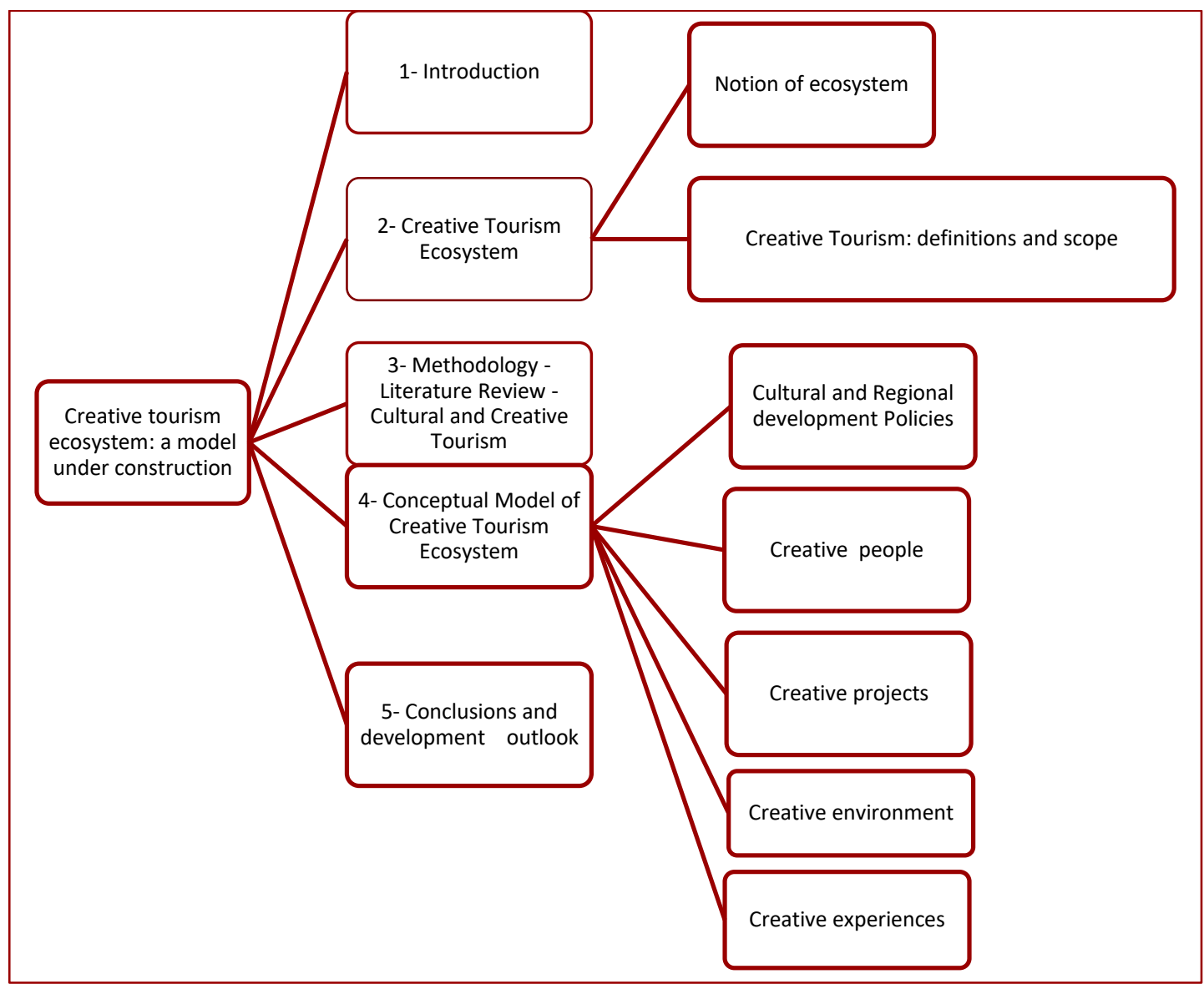

Table 1. Summary of the key concepts of the cultural and creative tourism ecosystem

\begin{tabular}{|l|l|l|}
\hline Creativity & $\begin{array}{l}\text { Harrington (1999) and } \\
\text { Shandwick (2015) }\end{array}$ & $\begin{array}{l}\text { Commitment to "Creative People", "Creative Projects" and } \\
\text { "Creative Environment" as a means of providing "Creative } \\
\text { Experiences" with the power of transforming a region into an } \\
\text { important tourist destination. }\end{array}$ \\
\hline $\begin{array}{l}\text { Value } \\
\text { Constellation }\end{array}$ & $\begin{array}{l}\text { Prahalad and Ramaswamy } \\
\text { (2004) and Castells (1999) }\end{array}$ & $\begin{array}{l}\text { Focus on the consumer and the provisions of unique } \\
\text { experiences where different actors collaborate and contribute } \\
\text { to the value creation process. }\end{array}$ \\
\hline Coopetition & $\begin{array}{l}\text { Hudson and Ritchie, (2009) } \\
\text { and Ritchie and Hudson } \\
\text { (2009) }\end{array}$ & $\begin{array}{l}\text { By using collaborative strategizing, organisations and } \\
\text { destinations can offer memorable tourism experiences to } \\
\text { potential visitors and ensure sustainable product competitive } \\
\text { advantages over competitors/places. }\end{array}$ \\
\hline $\begin{array}{l}\text { Cultural } \\
\text { Landscape }\end{array}$ & Chronis (2012) & $\begin{array}{l}\text { Destinations should be seen as cultural landscapes where the } \\
\text { physical environment is shaped and transformed through } \\
\text { history. }\end{array}$ \\
\hline
\end{tabular}

The main challenge for those in the cultural tourism sector will be to create memorable experiences in order to acquire loyal customers (Cole \& Chancellor, 2009; Saayman \& van der Merwe, 2014). According to Richards (2001) there are four issues concerning creativity which can improve cultural tourism: it is able to generate value, it encourages regional innovation, it is sustainable and it is mobile. To give more detail on each of these points: 
1) Due to its scarcity, creativity can easily generate value. It is an attribute which relatively few people possess. Within the cultural tourism market, attractions do not make their location distinct, as indeed every city has museums and monuments. Landry and Bianchini (1995) suggest the benefits of innovating a "creative city" as a new means of differentiation.

2) Creativity allows destinations to innovate their tourist supply and to make unique experiences available, providing the co-creation of value in the tourist experience and offering unique competitive advantages in comparison to other destinations.

3) Creativity is a process and creative resources are more sustainable; unlike physical cultural attractions such as museums and monuments which deteriorate over time, creative attractions are renewable.

4) Creativity is mobile, as artistic performances and works of art can be produced practically anywhere and have no need of a dedicated infrastructure.

The resulting model highlights the key drivers linked to tourism and the cultural and creative industries. It is based on legislation (European, national, regional and sector-specific) which, with the use of smart specialisation strategies, will benefit the development of these regions through positive discrimination. The model in section 5 closes the article with implications for the limitations of the conceptual model and some suggestions for the future development of cultural and creative tourism.

\section{The cultural and creative tourism ecosystem}

\section{- The concept of ecosystem}

The origin of the term "system" derives from biology and refers to the complex and interdependent biological environment, where genetic information, encoded into DNA molecules, is the foundation of life on Earth. In the economic environment, technological and business information which is recorded in books, research, scientific journals, databases and is conducted by millions of individuals, is the life source of the economy.

Ackoff (1981) summarises the concept as a system of a group of two or more elements which must fulfil three conditions: i) the behaviours of each element affect the behaviour of all the elements within the group; ii) the elements' behaviours and their impact on the network are symbiotic; and iii) no behaviour within the group is independent as the effect of each spreads to the others. For the survival and success of systems or ecosystems, Tansley (1935) recommends strategies sustained by competition and cooperation between its participants, in other words, coopetition. Boley and Chang (2007) outline four critical elements of ecosystems: (1) interaction and involvement of stakeholders; (2) balance and harmony between players; (3) shared aims and objectives and (4) self-organisation.

In support of the above ideas, Moore (1993) argues that an organisation doesn't just belong to one specific industry but is a part of an ecosystem of businesses. This ecosystem extends across a variety of sectors and distribution channels, involving a set of innovative microeconomic ideas in constant coevolution, where the relationships and strategies of its stakeholders have a profound impact on the partners competitiveness. 
The concept of a tourism ecosystem is nothing new, as tourist experiences have always demanded broad coordination and collaboration between different agents within the industry and governmental organisations (Mill \& Morrison, 2002). In the tourism context, there exists a complex set of organisational networks which extend across different scales/industries/spatial activities, connecting various types of stakeholders who form symbiotic relationships in order to increase individual benefits and achieve shared goals and thus guarantee the success and sustainability of the system.

In the tourism ecosystem, companies can integrate horizontally (to increase their market participation), vertically (to control different production cycles in their businesses) and diagonally (Poon, 1993) to selectively connect with their target market and systematically bring together the range of services necessary to keep them engaged (via technological communication and information platforms).

Thus, ecosystems bring together a more holistic understanding, as they recognise that small changes can cause substantial effects across the various systems they are composed of. In addition, they put the focus on complex relationships and incentivise dynamic changes.

Cultural and creative ecosystems incorporate creative industries, creative spaces, creative projects and creative people (Harrington, 1999; Shandwick, 2015). The term "creative industries" emerged in the 1990 s to describe sectors where creativity was key to the growth of businesses and regions. Initially, creative industries referred to the activities of cinema, theatre, music and the visual arts, and now include different areas connected to tangible and non-tangible heritage, and constitute a powerful means of imparting the sentimental value in the heritage of regions, traditions, objects, places and social practices.

This category of "heritage (re)valorization" entails new uses and the regeneration of the tangible heritage and ways of (re)discovering the intangible heritage of the regions. Fortuna (2012) introduced the concept of tradition "detraditionalisation" (which implies the recognition of the ontological autonomisation of heritage assets), considering that the heritage action entails the consecration of certain objects, places or social and cultural practices. These arise (re)invested with historical significance, even if they no longer have a meaningful connection to current collective life or to what their function and meaning was in the past. Fortuna (2012: 25), quoting Aloïs Riegl ([1903] 1984) on "the modern cult of monuments" states that modern subjects assign value and meaning to those assets and resources, updating the meaning of heritage according to their own valuing systems.

\section{- Cultural and creative tourism: Definitions and context}

"Creative tourism" is considered a new generation of cultural tourism.

(Ohridska-Olson, 2010: 2)

The concept of "creative tourism" is considered an extension of "cultural tourism" (Richards, 2005; Richards \& Wilson, 2006b, 2006c), and a key element of the creative ecosystem (Harrington, 1999). It emerged in response to dissatisfaction with experiences provided by 
cultural tourism and a lack of creative and exciting tourist options with the potential to enrich visitors and connect them to local communities (Smith, 2005).

Traditional cultural tourism is based on passively "observing" and "contemplating" (for example visiting museums and art galleries or watching concerts and ballet performances). Creative tourists seek out experiences which go beyond simply observing cultural displays; they crave the opportunity to "experiment" (Pine \& Gilmore, 1999) and participate (for example wine tasting, workshops and courses in painting, dance, cooking, etc.) in order to awaken their senses while having the experience.

The continual search for emotional experiences plays a key role in the development of tourism. The different ways of perceiving these experiences are seen as social disputes of meaning, including storytelling. Choay (2006) states that there is significance attributed to objects, places and sociocultural practices which, from a more or less distant past can bring heritage into the present in which they seek to blend.

In reinforcement of this idea, Richards and Raymons (2000) defined creative tourism as an opportunity for visitors to unlock their creative potential by actively participating in experiences and learning new things. These tourism consumers are seen as active participants in their experience and co-creators of values in the tourist ecosystems (Vargo \& Lusch, 2008). Within this framework of thought, in 2006 UNESCO deemed creative tourism as an engaged and authentic experience, providing an active education in the arts, heritage or specific aspect of a place enabling a connection with local hosts and bringing a culture to life.

Supporting this notion, Blapp (2015) depicts creative tourism as offering its visitors the opportunity to participate in a wide range of activities linked to the destination in areas such as music, visual arts, theatre, sport, gastronomy, spiritual activities, languages, art workshops and writing. There exists a strong interaction between hosts and guests.

Creative tourism therefore depends on endogenous resources of places to attract visitors to the destination, while also providing a way to encourage creative community development, supporting creative industries, and improving the local economy. Within the concept active verbs such as "participate", "learn", "involve", "do" and "learn" stand out, placing creative tourism as the next generation of cultural tourism. It raises customer satisfaction levels and satisfies the visitor's need for self-fulfilment, while focusing on the development of skills with a practical use.

\section{Research methodology}

Besides being a means of applying knowledge, the research process is also a process of planning and controlled creativity (Hill \& Hill, 2000). The authors identified the creative tourism ecosystem as a potential means of developing low-population density areas. Presupposing the challenging relationship between supply (through the use of coopetition strategies; calling on the involvement of local representatives with visitors and by recognising creativity as a resource which supplies new opportunities and prosperity) and demand (through the co-creation of value in tourist experiences) with the potential of being assisted by information and communication technologies (ICTs), the aim is the area's 
sustainable development. The unique and differentiated development of regions should put the talent and culture of a place's inhabitants at the forefront of policy making (European, national, regional and sectorial) promoting cultural diversity, protecting and safeguarding heritage and contributing to cultural and creative industries to boost job creation and regional progress.

The study begins by identifying the actual size of small dimension areas in Portugal. According to the report "Low-population density areas, high-potential areas" 1 two thirds of Portuguese land (Figure 2), correspond to municipalities in the country's interior and are also identified as low-population density areas. This document also lists the effects caused by the depopulation of the country's interior: physical desertification caused by the abandonment of land and productive activities; the decline in business operations and the loss of critical mass - demographic, social, economic and even institutional; the rise in cost of the provision of infrastructure and equipment for public use; the scarcity of fundamental public services and the corresponding damage to equal opportunities and living conditions. Thus, all business initiatives linked to cultural and creative tourism will be a huge asset to these vulnerable areas.

Figure 2. Portugal: Low-population density areas

No LOW-POPULATION-DENSITY MUNICIPALITIES: 165

No LOW-POPULATION-DENSITY PARISHES IN MUNICIPALITIES WHICH DO NOT HAVE LOW POPULATION DENSITY: 73

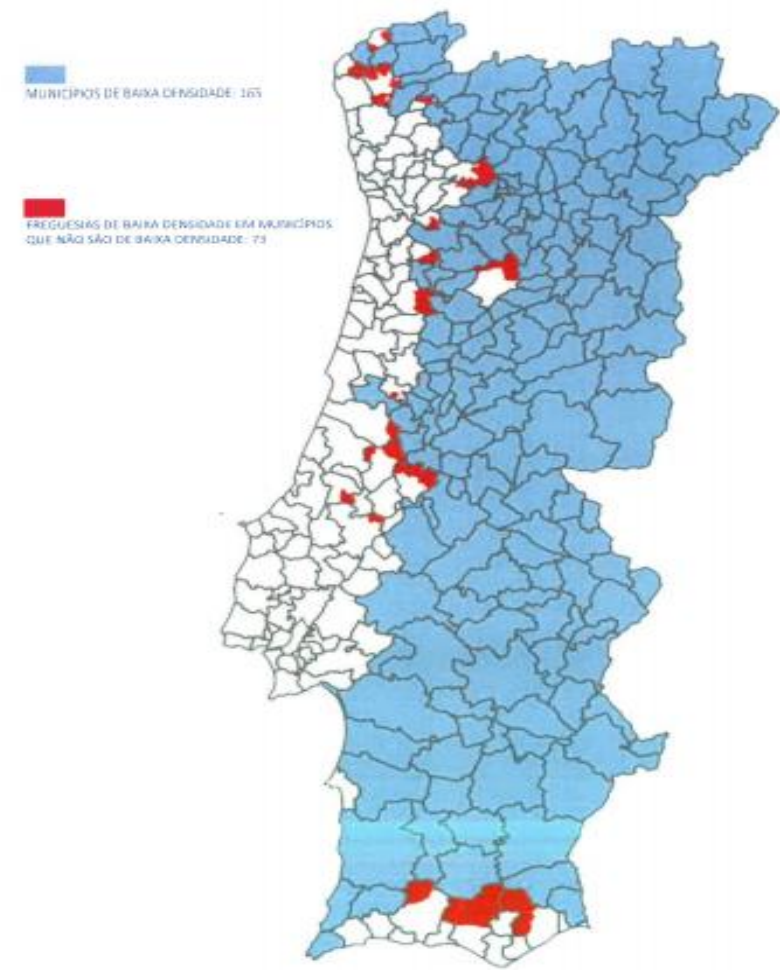

Source: Produced by CIC Portugal 2020

https://poseur.portugal2020.pt/media/37819/delibera\%C3\%A7\%C3\%A30_cic_pt2020_01072015_territori os_baixa_densidade.pdf

'https://poseur.portugal2020.pt/media/37819/delibera\%C3\%A7\%C3\%A30_cic_pt2020_01072015_territori os_baixa_densidade.pdf 
The next step in the study was a literature review considering as search criteria TITLE-ABSKEY ("Creative Tourism") conducted between April and August 2017, from which emerged 67 scientific articles from journals found on the Scopus database, in order to understand the state of the art in this field. Studies from the following countries were found: Italy 6; Spain 6; Taiwan 6; Thailand 5; China 4; the Netherlands 4; Czech Republic 3; Iran 3; Portugal 3, demonstrating that there is some awareness of this theme across Europe and Asia are aware of this theme.

The research was found in papers from the following years; 2017 (2); 2016 (13); 2015 (10); 2014 (10); 2013 (5); 2012 (4); 2011 (4); 2010 (5); 2009 (4); 2008 (2); 2007 (4); 2006 (2); 2005 (0); 2004 (1); 2003 (0); 2002 (1), indicating that this is a theme that is progressively gaining interest.

The thematic area of creative tourism was found predominantly in: Business, Management and Accounting (39); Social Sciences (36); Economics, Econometrics and Finance (13); Computer Science (9); Engineering (8); Environmental Science (6); Arts and Humanities (3); Earth and Planetary Sciences (3); Agricultural and Biological Sciences (1). In summary of the scope of analysis of the theme "Cultural and Creative Tourism", (as demonstrated by Table 2) it is clear that there is a long road ahead in the search for a structured and planned strategy for the growth of this type of tourism, as well as a huge diversity of approaches to this theme.

Table 2. Literature review: Different directions in the approach to the framework for cultural and creative tourism

\begin{tabular}{|l|l|l|l|l|}
\hline $\begin{array}{l}\text { Territorial Planning } \\
\text { and Tourism }\end{array}$ & $\begin{array}{l}\text { Cultural Tourism } \\
\text { - Events }\end{array}$ & Rural tourism & Marketing & $\begin{array}{l}\text { Strategic } \\
\text { management }\end{array}$ \\
\hline $\begin{array}{l}\text { Creative Tourist } \\
\text { Experience }\end{array}$ & $\begin{array}{l}\text { ICT and social } \\
\text { media for sharing } \\
\text { experiences }\end{array}$ & $\begin{array}{l}\text { Creative } \\
\text { perspectives on } \\
\text { cultural tourism }\end{array}$ & $\begin{array}{l}\text { Co-creation } \\
\text { of value }\end{array}$ & $\begin{array}{l}\text { Synergies between } \\
\text { creative industries } \\
\text { and tourism }\end{array}$ \\
\hline $\begin{array}{l}\text { Creative tourism } \\
\text { models }\end{array}$ & $\begin{array}{l}\text { Creative tourism } \\
\text { logistics }\end{array}$ & $\begin{array}{l}\text { Creative } \\
\text { policies }\end{array}$ & $\begin{array}{l}\text { Creative } \\
\text { residences }\end{array}$ & $\begin{array}{l}\text { Integration of creative } \\
\text { tourism in different } \\
\text { sectors }\end{array}$ \\
\hline
\end{tabular}

Detailing each perspective:

\section{- Land planning and tourism}

Sofiel, Guia and Specht (2017) highlighted the importance of land planning, design and management of public spaces in order to improve urban environments and the quality of life for those living there, emphasising the improvement of community social well-being.

\section{- Cultural tourism and cultural and social development}

Markwick (2017) demonstrated the potential of European Capitals of Culture for the promotion and growth of tourism. Wattanacharoensil and Sakdiyakorn (2016) established the key role played by community leaders and their outlook on the management and growth of communities, as well as identifying factors that could advance and complicate the 
development of creative tourism in specific destinations. Della Lucia, Trunfio and Go (2016) put forward a conceptual framework based on the public-private partnership for exploiting cultural heritage and the possible implications for urban tourism. Gülüm (2015) associated cultural tourism with creative tourism, discovering the importance of local and regional customs and experiencing authentic cultural practices. For Gülüm, each area can potentially offer modern tourists increased connection with the landscape by living like a local, which seems to be the main attraction in the new generation of post-modern tourism. He reinforces the idea that, whereas traditional cultural tourism is based on seeing and watching, creative tourism is born from experiences, active participation and learning.

\section{- Marketing and communication}

Koudelková (2017) addressed the key role of communication and marketing for small and medium-sized businesses in the growth of creative tourism.

\section{- Strategy and creativity in business management}

Suárez and Fernández (2015) focused their attention on the relationship between creativity and tourist cities, with the aim of exploring the specific importance of local tourist systems. For this they use the term Creacity, which consists of three dimensions (spatial, environmental and institutional), all of which correlate with each other.

\section{- Creative tourist experience}

Messina, Gega and Pulido-Fernández (2017) examined tourist experience, proposing policies and campaigns. They recommended investments in the field of human resources, suggesting respective approaches to training which allow a more suitable service to be projected and provided in line with visitors' expectations; Hung, Lee and Huang (2016) sought links between a memorable creative tourism experience and revisit intention; Fernandes and Rachão (2014) pinpointed local know-how and creative abilities as a form of creative tourism, exploring the attitudes, expectations and motivation of visitors in determining how a destination can reinvent its strategy for tourist products based on heritage and discover emerging trends in the regional tourist market; Booyens and Rogerson (2015) focused their investigation on cultural experiences and the growth of urban tourism as an example of the innovation of tourist practices; Stamboulis and Skayannis (2003) considered experience as a new framework within tourism, supported by strategies associated with the development of information related to the user and by ICTs which are incorporated into the whole tourism value chain; Pirita Ihamäki (2012) included the concept of Geochachers in creative tourist experiences.

\section{- ICT - Social networks; creating and sharing experiences}

Štefko and Mudrík (2016) focused on the use of ICT and social networks as a tool of creating and sharing creative tourism experiences. 


\section{- Creative tourism perspectives - Demand side}

Tan, Tan, Luh and Kung (2016) focused on the demand side of tourism, identifying three groups of tourists; relaxers, sensation-seekers, and existential-type. Ali, Ryu and Hussain (2016) used structural equations to show how creative experiences are significant for tourists, staying in their memory by attaining remarkable levels of satisfaction and influence over behavioural intentions; Richards (2011) argued that the surge in "creative tourism" further spreads the growing integration between tourism and the different initiatives of the creative industries, creative cities and the "creative class".

\section{- Co-creation in creative tourism}

Bruin and Jelinčić (2016) focused on the active role of tourists in the creative tourist experience. They considered the way in which, although the "creative shift" in everyday life has led to the rapid growth of creative tourism, not all forms of creative tourism incorporate the same intensity of creative involvement. It is possible to distinguish between passive and active involvement. Concurrently, a "social shift" created a rise in popularity in other forms of tourism, such as volunteer tourism, which involve active participation; Tan, Luh and Kung (2014) characterised the concept of co-creation in creative tourism, defining a type of tourist, the prosumer and identifying five groups of these tourists; on the other hand Ngamsirijit (2014) proposed an additional approach in value creation, including intellectual capital and behaviour within the network of systems or tourist companies; Chang, Backman and Huang (2014) focused on creativity in the field of tourism, as a useful strategy in reinventing territorial, cultural and social spaces. These authors examined the psychology of the consumer tourist in the context of creative tourist destinations, identifying motivation, perceived value and satisfaction as three factors affecting whether or not visitors repeat their tourist experience.

\section{- Synergies between creative industries and tourism}

Booyens, and Rogerson (2015) highlighted the synergies between creative industries and tourism. They considered creative tourism based on experience to be a niche market of urban tourism with considerable potential for growth. They pointed out that creative events, as well as initiatives by the creative industry are progressively growing, despite not being well integrated in the mix of tourist destinations. They suggested critical policies that could develop creative networks, boost the demand for creative tourism, cultivate a mix of creative touristic products, plan the growth of a creative space and integrate create tourism into the image of the destination; Alvarez (2010) considered strategies and creative tactics for the cultural regeneration of particular areas, permitting differentiation; Daniel (2014) explored the potential of cross-industry partners with the creative industries.

\section{- Creative tourism model}

Rabazauskaite (2015) proposed a model for creative tourism which incentivises the use of creative workshops in the process of revitalising public spaces. He further focused on the 
creative process of cultural production and active learning about the destination which involves both tourists and residents. As a result, there is a generation of unique travel experiences, and a growth in skills or production of sustainable objects, which contribute to the revitalisation of regions. In creative tourism, a city, its atmosphere, community art initiatives and other local creative local activities are seen as tourist attractions, transforming the tourist into an active participant in these cultural processes; Richards (2014) considered creativity important in the development of tourism within regions. Thus, the extent of competition between regions grows as they search for ever more ways to distinguish themselves via creative strategies. He proposed a conceptual model which highlights the different methods of involving creativity in tourism, including: the development of innovative products and experiences; the revitalisation of existing products; the appreciation of cultural and creative local assets; economic growth through the creation of spin-offs for creative development; the use of creative techniques to improve the tourist experience; the addition of atmosphere and 'buzz' to places; Tan, Kung and Luh (2013) reflected on how creativity in creative tourism refers not just to "environment", "people" and "product/service/experience", but also extends to "conscience", "needs" and "creativity". These elements interact with tourists' emotions throughout their experience.

\section{- The logistics of tourism for creative tourism}

Ngamsirijit (2015) examined the logistic development of creative tourism, which requires an understanding of the behaviour and needs of tourists, alongside the conception of a logistical system for their reception.

\section{- Policies}

Wattanacharoensil and Schuckert (2016) highlighted the contribution of the creative tourism policy-making; Hingtgen, Kline, Fernandes and McGehee (2015) detailed the impact of the reduction of state jobs in these areas and its consequences for entrepreneurship. Residents tend to exploit the potential for tourism, developing more creative tourist products.

\section{- Creative residences}

Whiting and Hannam (2014) approached the concept of creative residence, showing that creative tourism destinations already promote artistic ties with other cities, offering artists opportunities to meet and collaborate with colleagues from similar areas.

\section{- Creative tourism - Hotel industry}

Salmna and Uygur (2010) associated creative tourism with the hotel industry, aiming to understand how creative tourists can influence hospitality, as they move between creative and standardised spaces. Richards and Wilson (2006a) argued that, as culture is more used as a means of social and economic development, the market of cultural tourism is flooded with new attractions, cultural routes and heritage resources. However, many consumers, tired of finding the same reproductions of culture in different destinations, seek other 
options. The increase in qualified consumption, the importance of identity formation and the acquisition of cultural capital in the (post) modern society point to the use of creativity as an alternative to conventional cultural tourism.

\section{- Most frequently used methodologies}

The most frequently used methodologies in the 67 articles studied include: case studies, quantitative and qualitative analysis, field studies, structured and semi-structured interviews, focus groups, participant observation research and comparative studies.

Therefore, approaches to the topic of cultural and creative tourism are as diverse as the areas of art and culture, with an enormous potential for diversification and singularity in the proposals for tourist experiences.

\section{The ecosystem model for creative tourism: A vision}

Based on a critical view, a conceptual model for cultural and creative tourism (Figure 3) was designed based on the literature review and on the concepts of the creative ecosystem advocated by Harrington (1999), Shandwick (2015), Prahalad and Ramaswamy (2004), Castells (1999), Hudson and Ritchie, (2009), Ritchie and Hudson (2009) and Chronis (2012), which includes 3 basic elements: creative people, creative projects and creative environments and all of the functional relationships between them. These factors were based on European, UNESCO, National, Regional and Sectoral policies acting as agents of regional development harmonization and stimulation.

Figure 3. The ecosystem model for creative tourism: Proposal

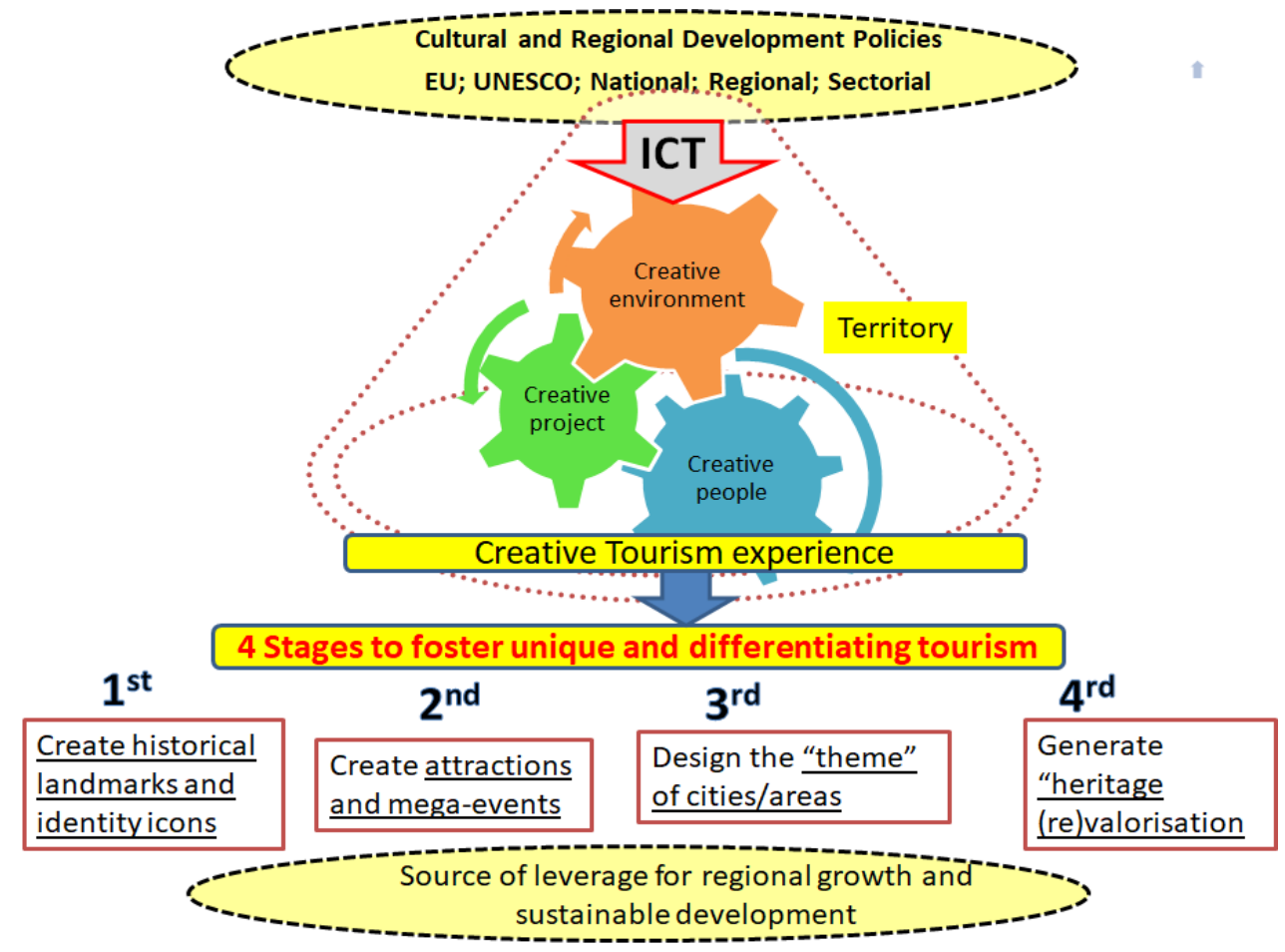

Source: Own production based on Harrington (1999), Shandwick (2015), Prahalad and Ramaswamy (2004), Castells (1999), Hudson and Ritchie, (2009), Ritchie and Hudson (2009) and Chronis (2012). 
They are supported by ICTs as a catalyst for processes (innovation, brainstorming, creation, development, implementation, dissemination, communication, distribution and feedback). Later, strategies related to supply (co-participation amongst all stakeholders as enablers of sustainable development) and demand (co-creation of experience value by the visitor) were joined to these factors so that in conjunction they could be a source of regional growth and sustainable development leverage.

As a result, industries based on creativity and culture are a source of value leverage for inclusive economic growth, sustained social well-being, democratisation of cultural heritage and strong environmental concern, generating a continuous spiral of political interest at a European, national and sectorial level.

Reinforcing all these ideas, Duxbury, Silva and Castro (2019: 14) advocated:

Through locally developed creative tourism activities, this attachment to a place, both affective and 'knowledge-enriched' - can be shared with visitors. This sharing process contributes to strengthening local identity and knowledge as well as to building a more ephemeral cognizance of dynamic means of meaning-making and, especially, the capacity of creative processes to probe and articulate aspects of place attachment and to spark memory-making among both visitors and residents.

By detailing each of the attributes of the ecosystem of creative tourism, the "Policies of Cultural and Regional Development", the "Creative ecosystem: Creative people, Creative projects and Creative environment" and the "Creative Touristic Experience" can be approached. The subsequent initiative, which supports the design of the model, was to enumerate (though not exhaustively) European, national, regional and sectorial legislation with positive discrimination policies for low-population- density areas.

\subsection{Cultural and regional development policies}

Gee \& Fayos-Solá (1997) highlight "Policy” as a high-level general plan which includes aims and procedures, usually found in formal manifestos, as well as laws and official documents and declarations. For an effective and efficient formulation of cultural and creative policies, evidence of the value generated by the activities and the impact on societies and regions is required (Table 3 ).

Table 3. Guiding documents for area development policies

\begin{tabular}{|l|}
\hline United Nations Conference on Trade and Development (UNCTAD, 2015): ${ }^{2}$ CREATIVE ECONOMY \\
OUTLOOK AND COUNTRY PROFILES: Trends in international trade in creative industries \\
\hline EUROPE - Creative Europe Programme (2014 to 2020) in Regulation (EU) N ${ }^{1295 / 2013}$ \\
\hline UNESCO \\
\hline National: ENEI - National Strategy for Smart Specialisation \\
\hline Regional: EREI - Regional Strategy for Smart Specialisation \\
\hline Sectorial: TURISMO 2020 - Five principles for one ambition \\
\hline
\end{tabular}

Source: Own elaboration based on Director, International Trade in Goods, Services and Commodities Division United Nations Conference on Trade and Development (UNCTAD).

${ }^{2}$ Details in https://unctad.org/en/PublicationsLibrary/webditcted2016d5 en.pdf 
- United Nations Conference on Trade and Development (UNCTAD, 2016): Creative economy outlook: Trends in international trade in creative industries

According to Guillermo Valles, Director of the International Trade in Goods, Services and Commodities Division of UNCTAD (2015), the creative economy is an important part of global trade. The report considered "The global market for traded creative goods and services totalled a record of $\$ 547,513$ millions of dollars in 2012 , as compared to $\$ 302,058$ billion in 2003 ". 3 Annual growth rates stood at 8.6\% from 2003 to 2012, showing the strength and resilience of the industry, despite the economic downturn in the world economy. Exports from developing countries, particularly from Asia, are growing faster than in the developed world. As regards sectorial exports of goods from creative industries in 2012, around 69\% were accounted for by design and new media and the remaining $31 \%$ by publications, visual arts, handicrafts, the audiovisual and performing arts.

According to UNCTAD (2015: 120), the exports from creative industries in Portugal grew from US\$1,358.7 million in 2003 to US\$1,762.2 million in 2012. In Portugal, design and handicrafts are the creative products with the greatest growth between 2003 and 2012. ${ }^{4}$ The greater Lisbon area is the most creative in Portugal. Around 30\% of creative employment originates in this area from almost 22 thousand businesses in this sector. ${ }^{5}$ Portugal's largest export market for creative goods is Europe, with $67 \%$ of exports, followed by Africa (18\%), America (10\%) and Asia (4\%). France, Spain, Angola, the United States and Germany are the main export markets for creative products in Portugal.

\section{- EUROPE - Creative Europe Programme (2014 to 2020)}

Regulation (EU) N $\mathrm{N}^{\circ}$ 1295/2013 of the European Parliament and Council of $11^{\text {th }}$ December 2015 recognises the intrinsic and economic value of culture in Article 5 "European added value" of the Creative Value Programme (2014 to 2020). The "Europe 2020 Strategy" defines a way of transforming the European Union into a smart, sustainable and inclusive economy, which offers high levels of employment, productivity and social cohesion. The Commission stated that the EU needed to provide more attractive framework conditions for innovation and creativity. In this sense, the cultural and creative sectors (as a source of innovative ideas which can be transformed into products and services) can create growth and employment and help in the approach to social changes. It has been suggested that excellence and competitiveness in these sectors is a result of the efforts of artists, creators and professionals, who, therefore need better conditions in order to access financing.

\section{- UNESCO - United Nations Organization for Education, Science and Culture}

UNESCO's cultural activities strive for the safekeeping of cultural heritage, the stimulation of creation and creativity and the preservation of cultural entities and oral traditions, as well as

\footnotetext{
${ }_{3}^{3}$ Details in https://unctad.org/en/PublicationsLibrary/webditcted2016d5_en.pdf, p 2.

4 UNCTAD/WEB/DITC/TED/2015/5 - Creative Economy Report / Country Profiles (2015: 120).

${ }^{5}$ UNCTAD/WEB/DITC/TED/2015/5 - Creative Economy Report / Country Profiles (2015: 121).
} 
the promotion of books and reading. This entity has been promoting tangible and intangible heritage, particularly through the 2003 UNESCO Convention for Safeguarding Intangible Heritage and the 1972 UNESCO Convention on Protection of World Cultural and Natural Heritage. Its aim is to contribute to the valorisation of the most relevant heritage in our history, giving people a sense of ownership of cultural heritage and its historical value. On the other hand, the 2005 UNESCO Convention, which came into force on $18^{\text {th }}$ March 2007 and of which the EU is part, highlights that activities, goods and cultural services have an economic and cultural nature, because they pass on identities, values and meanings and should not be treated as having only commercial value. The aim of this Convention was to strengthen international cooperation, including international coproduction and coding agreements and solidarity to favour the cultural expression of all countries and individuals. It is also stated that special attention should be given to the special circumstances and needs of various social groups, including people belonging to minority groups. Therefore, a support programme for the cultural and creative sectors should promote social diversity at an international level, according to the Convention.

\section{- Estratégia Nacional Especialização Inteligente (National Smart Specialisation Strategy) $(\mathrm{ENEI})^{6}$}

According to ENEl's vision for 2020, Portugal must consolidate or bring to the forefront its leadership in green economy, digital economy, and blue economy through the use and development of the advantages acquired in information and communication technologies and in new materials, and through sustainable exploitation of endogenous resources, such as the sea, forestry and minerals. Emphasis is given to major societal challenges such as climate change, risk mitigation, biodiversity, water, and ageing, in coordination with sectorial strategies (sea, energy, tourism, agro-food and forestry). This document systematizes the strengths, weaknesses, threats and opportunities identified in a joint way and the four pillars of the IS\&I's (Smart Specialization and Innovation) Vision for 2020:

- Digital Economy (Portugal as a European actor in ITC);

- Portugal as a country of science and creativity (To explore existing capacity in energy, biotechnology and health; to stimulate cultural and creative industries; to value national identity and tourism);

- Intensify the technological capacity of industry (Reinforcement of the technological intensification of industry; insertion in international value chains; exploitation of existing capacity in new materials; development of capacities in automotive, aeronautics and space and in transportation and logistics);

- Value differentiating endogenous resources (Development of innovative ecosustainable products with high added value; sea economy, forestry, mineral resources and agro-food).

\footnotetext{
6 https://www.ani.pt/media/5238/enei-2014.pdf
} 
ENEI identifies five structuring objectives for five thematic axes, which encompass the 15 smart strategic priorities. ${ }^{7}$ Regarding Axis 5 - Cultural and Creative Industries, the following are the main lines of action: Vision: Portugal as a credible cultural nationally and internationally recognised producer, strengthening the Portugal brand in a global context. Characteristics: Emerging activity with great potential for growth and economic and cultural value. Competitive advantages: National identity (historical, cultural, linguistic and technological); internationally recognised quality of architecture, national design, and fashion; products of cultural industries with potential for internationalization, through the strengthening of sectors related to linguistic and historical production; the country's technological ability and human resources.

Thus, there is great potential for accelerated valorisation of new products with the potential to promote these at an international level, including in the area of cultural and creative industries, event promotion and tourism.

\section{- Regional: EREI - Estratégia Regional Especialização Inteligente (Regional Smart Specialization Strategy) ${ }^{8}$}

This network encompasses Thematic Operational Programmes in the mainland, Regional Operational Programmes in the mainland (5 regions: North, Centre, Lisbon, Alentejo and Algarve), Regional Operational Programmes in the Autonomous Regions (Azores and Madeira) and Rural Development Programmes, amongst others. As for the regions, there is integration between the RIS (Research and Innovation Strategy for Smart Specialization), the Regional Action Plan (RAP) and the Regional Operational Programme (ROP). There is a unique plan in each region designed according to the potential of the endogenous resources and infrastructures of the areas and the regional agents that they include. They aim to consolidate the regions as innovative spaces, mobilizing individual and collective potential.

\section{- Sectorial - TOURISM 2020 - Five principles for one ambition9}

Since 2007, Portugal has had a National Strategic Tourism Plan (PENT - Plano Estratégico Nacional do Turismo), approved by the Resolution of the Council of Ministers no. 53/2007, of April 4, which was developed for the time frame 2006-2015, and which underwent two revisions. Five principles harmoniously aligned to fulfil the ambition to transform Portugal into a more agile and dynamic tourist destination in Europe were defined for 2020: People, Freedom, Openness, Knowledge and Collaboration. The operational logic encompasses the ambitions of qualification (to grow more than the competition) and competitiveness (to be in the top 10 most competitive destinations in the world) for Portugal as a destination in the areas of sustainability, quality and competitiveness. On the other hand, the aim is an entrepreneurial, effectively managed destination linked to the world, and a destination that

\footnotetext{
${ }^{7}$ https://www.ani.pt/media/5238/enei-2014.pdf (pages 30 and 45).

${ }^{8}$ https://www.portugal2020.pt/Portal2020/programas-operacionais-portugal2020-2 9 http://www.turismodeportugal.pt/PORTUGU\%C3\%8AS/TURISMODEPORTUGAL/DESTAQUE/Documents/turismo2020-cinco-principios-para-uma-ambicao.pdf
} 
with its own stamp, whose promotion and commercialization strategies must arise from technical, not political, visions in order to achieve efficiency.

All policies are therefore in tune with this dynamic of creativity in order to build agile, dynamic, competitive and creative tourism destinations based on a creative ecosystem (people, projects and creative environments).

\subsection{Creative people}

With regard to ecosystem resources (creative people, creative environment, and creative projects), there is a notable increase in creative activity levels, as well as the definition of rules and rewards for involvement in tasks, encouraging participants to "take a hands-on approach". There is also an incentive to "play" with ideas and materials, quick and easy access to materials, space and time, confidence in the creative abilities of the participants within the environment, the predominance of accurate information about creative processes and personal development focused on creative activities. The environmental wealth brings all these elements together and allows for work of quality and authenticity.

As for personal resources, the following are listed as elements fundamental for creativity: motivation; courage; curiosity and willingness to explore; confidence in one's own abilities and skills; awareness that creativity often involves substantial periods of discouraging work; willingness to take risks and tolerance of ambiguity. It is important to highlight that a crucial part of ecosystems is the combination of different visions, experiences and varied knowledge, allowing for a better understanding of the real problems of the regions. Another imperative aspect of ecosystems is the creation of teams which can instigate new companies in the market, which are vital foundations for the coming together of stakeholders.

\subsection{Creative projects}

According to Corina Crețu (European Commissioner for Regional Policy), ${ }^{10}$ shifting to a knowledge-based economy requires taking risks by connecting the quadruple helix actors citizens, companies, administrations and academia - and constantly being at the forefront of innovation. These innovation ecosystems are self-organizing and evolve through interaction between top-down political choices and bottom-up creative forces. In this environment, the role of public policies is to promote the connection between actors in innovation and facilitate the process of discovering new opportunities, either through the provision of resources such as education or infrastructures, or through the coordination of demand, such as public procurement.

\subsection{Creative environment}

The creative environment is attentive to the physical, social and cultural environment where activity occurs, with the aim of solving problems or developing projects. As for solving

\footnotetext{
${ }^{10}$ Available at http://cor.europa.eu/en/documentation/brochures/Documents/Regional-innovationecosystems/Regional-innovation-ecosystems.pdf
} 
problems within these areas, the Smart Cities Council highlights both traditional strategies or smart solutions can be used. For example, planning or citizen involvement issues are addressed very differently when adopting one strategy or the other. With regard to the planning of traditional regions, the approach is ad hoc and decentralised, with low cost efficiency and limited investment scalability. If the same space becomes a smart region, its planning is more effective, coordinated and holistic, resources are shared, there are economies of scale and investments are scalable. In a traditional region, the involvement of citizens in the affairs of their area is limited and dispersed, and there is no optimal use of services. On the other hand, in a smart region, there is a strong online presence, citizens can easily find and use public services and participate in collective initiatives, there is two-way communication between government and people, specialised services focused on the individual citizen are available and they can contribute to and access data from other smart cities/regions in real time.

There are a number of examples of smart cities around the world, connecting governments, businesses and citizens with each other and with improved services and information, generating efficiency and improving the quality of life for all. Dubai, United Arab Emirates, Songdo, South Korea, Johannesburg, South Africa, Mexico City, Mexico, Singapore, San Diego, CA, USA and Barcelona, Spain are noteworthy. The smart cities movement is gaining momentum and is a proactive response to the challenges of population growth, urbanisation and climate change. According to Shandwick (2015), estimates indicate that the global market potential for smart cities - infrastructure development, technology integration and e-government, energy and security services - could reach US\$3.3 trillion by 2025. A great deal of this market potential will be achieved by collaborative investments in solutions and innovations focused on inclusion, sustainability and resilience.

Shandwick (2015) presents his vision of Smart Cities in terms of trends, context and opportunities. According to this author, these smart areas must become tangible, relevant and accessible. The success of the movement depends on the collective capacity to identify, implement and scale solutions and investments within and between regions. This requires a greater ability to identify the right partnerships, communicate complex ideas amongst stakeholders, and engage citizens in campaigns that galvanize support and action at all levels of collaboration, from local communities to network ecosystems which connect people and ideas throughout the region.

Transposing Shandwick's ideas (2015: 8), action plans in smart areas must consider challenges and opportunities, requiring strategies of Collaboration, Innovation, Harmonisation of Objectives, Problem solving and Dissemination of results.

This philosophy can be transposed to low-population density areas where there are notable tensions related to infrastructure, social, economic and environmental issues, using cultural and creative tourism as a tool for the development of each area. Thus, in terms of:

- Collaboration: Given the transversality of the creative tourism sector, governments, civic leaders and other stakeholders must anticipate, avoid and solve challenges through collaboration. Implementation of the action plan may include seeking 
collaboration with various organisations (government, business, education, nonprofit, think tanks, local communities, residents).

- Innovation: Due to greater expectations of transparency and faster cycles of disruptive technologies, municipalities can manage this complexity through creative/innovative strategies, implementing new processes, integrating different technologies and finding efficiency by bringing stakeholders together. Implementing the action plan could begin with an audit of existing processes, to understand what works, where advanced technologies can help, and which systems need to be revised. Next, it would be important to implement or accelerate the integration of data management to monitor processes and better diagnose challenges and identify patterns and improvements. The final step is pilot testing of technologies and processes from other sectors to solve municipal challenges and adapt the approaches outlined.

- Harmonisation: The smart cities movement has developed in isolation and in a fragmented way. It is thus crucial to create a common vision, language and approach, facilitating the sharing of best practices, dimensioning solutions and accelerating change. In implementing the action plan, it is important to identify the different smart cities movements, drawing up benchmarking actions and facilitating constructive dialogue and knowledge sharing. It would be crucial to develop studies that evidence and demonstrate best practices and innovations in this area.

- Resolution: It is common for municipal leaders to face competing priorities and divergent interests of stakeholders, making decision-making processes for guaranteeing solutions, which promote inclusiveness, sustainability and resilience, complex. It will be necessary to clarify how resources and solutions will be approved and allocated, putting social and environmental impact objectives at the top of the list of criteria. The implementation of the action plan will require measures to ensure that teams linked to creative tourism can build differentiating, inclusive, sustainable and resilient tourism experiences; equality in accepting ideas; integration of quality controls and other feedback mechanisms to continuously monitor progress towards social and environmental objectives and to ensure timely interventions to correct deviations.

- Dissemination: In many regions, stakeholders are neither informed nor involved in the projects that concern them. It is crucial to broadly disseminate knowledge, regularly convening stakeholders and centralising knowledge sharing. In implementing the action plan, the dissemination of knowledge requires the involvement of people and different organisations. It is also important to find compelling ways and channels for sharing information/knowledge/storytelling.

All these elements can therefore be transposed to tourism, in order to generate positive impacts in each area and exciting experiences for visitors. Tourism impacts are related to the changes or sequence of events caused by tourism development in the host locations. The variables that cause the impacts have different nature, intensity, direction and magnitude. 
Successfully promoting the image of a region in a globalised and competitive world depends on the visitors' perceptions and it is a complex task, which requires a coordinated effort between all stakeholders (political leaders, opinion leaders, clients/suppliers and potential clients/suppliers, investors and potential investors, tourists, communities and others). The next section addresses some examples of creative tourism already implemented in Portugal, although it is still a concept under construction in our own area.

Duxbury (2019: 79), referring to the CREATOUR project, argued that:

With the variety of creative tourism activities that can be developed, and broader packages designed around them, a diverse array of entrepreneurial opportunities can be linked to creative tourism. Beyond individual business initiatives however, creative tourism promises the possibility of generating economic and social added value to a region, inclusive modes of development, and a new perspective from which to reenvision ways to induce and augment the vitality of local cultural (and other) resources, both tangible and intangible.

\subsection{Creative tourist experience in Portugal}

The desire to travel, to encounter new peoples and new cultures has generated cultural globalisation and a need for unique tourist experiences. The presence of the local culture is still important in the formation of the identity of each area, giving it specific contours and allowing unique sensations. In turn, Richards and Wilson (2006a) consider creative tourism to be of a more sustainable nature than traditional cultural tourism (which is based only on the consumption of built environments), which contributes to the development of the destination (Lindroth, Ritalahti \& Soisalon-Soininen, 2007).

The strategies defined by Richards and Wilson (2006b) to foster unique and differentiating tourism have several stages: $1^{\text {st }}$ - Create historical landmarks and identity icons for the regions (Evans, 2003, 2005); $2^{\text {nd }}$ - Create attractions and mega-events or exhibitions (Garcia, 2004; Richards \& Wilson, 2006a); $3^{\text {rd }}$ - Design the "theme" of cities/areas and $4^{\text {th }}$ - Generate "heritage (re)valorisation", adapting creative tourism to the requirements of authenticity of the experience to be provided for the visitor. In this case, creative tourism is based on the authenticity which the experience provides to the tourist (Prentice, 2001; Reisinger \& Steiner, 2006; Steiner \& Reisinger, 2006) and the specific place where the creative experience happens may be a sign of its authenticity.

Based on the strategies outlined above, the following are examples of the Portuguese situation:

As regards the first strategy of creating historical landmarks or emblematic ventures which highlight the symbolic and identity icons of a particular area (Evans, 2003), we can suggest: 
a) A trip on the cod fishing boat "Santa Maria Manuela" and participating in the sailing activities. The cod fishing, also known as Faina Maior is a Portuguese cultural landmark. More details ${ }^{11}$ in https://www.santamariamanuela.pt/pt/viajar.

b) A second example is the Pop Galo by Joana Vasconcelos, presented at the Lisbon Web Summit as an icon of Portuguese culture, which will have an interactive website gathering the photographs taken by those who see it and a repository of information about the symbolism of the cockerel in Portuguese culture (see http://www.popgalo.com/lisboa/?lang=pt). ${ }^{12}$ In an interview with the newspaper Público, ${ }^{13}$ the artist said:

This is pop culture revisited. A mixture of unusual materials which together give a kind of new version of our environment. Here, I mix LED lights with tiles, and the LED lights give a technological side to this cockerel. And it's the technology that allows a greater interaction with the public" (...) "It's a traditional cockerel during the day, with its tiles and singing, and at night it's a cockerel of the future with light and music.

c) Another example could be the Portuguese Calçada in QR Code. In 2012 an innovative project that uses QR Code on Portuguese pavements was developed with the aim of promoting Lisbon as a tourist destination. ${ }^{14}$ In 2013 the same idea was implemented on the boardwalk of the beaches of Rio de Janeiro, which allows tourists to expand their knowledge about this wonderful city through a new technological resource.

Many cities use this latter strategy for creating attractions, mega-events or exhibitions, as a standard strategy for competing (Garcia, 2004; Richards \& Wilson 2006b, 2006c). According to the Turismo de Portugal website, ${ }^{15} 111$ mega-events have been planned in various regions (as of 07-07-2017), of which 21 are in the Porto and in the northern region of Portugal, 20 in Central Portugal, 30 in Lisbon, 9 in the Alentejo and Algarve, 7 in the Azores and 8 in Madeira, involving the following types: celebrations, gastronomy and wine, sports, fairs, music and

\footnotetext{
${ }^{11}$ The Santa Maria Manuela (SMM) was built in 1937, belonged to the legendary Frota Branca [White Fleet] and faced the adversities of the North Sea during the harsh cod fishing campaigns. Now completely renovated, it is a unique sailing ship used for tourism, with excellent conditions for trips, events and nautical experiences.

${ }^{12}$ Anyone who approaches Pop Galo with a mobile phone can access all the information on the site through a QR code. Joana Vasconcelos considers it a dynamic work, due to the information which will be added and to the journeys that it will make around the world, since it is separable, separating into eight parts, which gives it mobility. "It is a work that is being built throughout the trips that it makes and of the people that pass it", in other words, there is co-creation of value. Pop Galo is named after the relationship with pop art, the colours revealed by LED lights and the relationship with technology. In http://www.popgalo.com/lisboa/?lang=pt

${ }^{13} \mathrm{At} \mathrm{https://www.publico.pt/2016/11/02/culturaipsilon/noticia/um-galo-de-barcelos-gigante-e-}$

tecnologico-a-beira-do-tej01749707

${ }^{14}$ See https://www.youtube.com/watch?v=J1aheziJOow.

${ }^{15}$ At https://www.visitportugal.com/en/encontre/grandes-eventos/list
} 
others (urban art, historical recreations, university festivals). However, when consulting local authorities and public and private cultural entities' websites, the number of events organised in the regions grows exponentially.

Andanças Festival, ${ }^{16}$ which promotes popular music and dance as a prime means of learning and exchange between generations, knowledge and cultures, is an example of creative tourism linked to mega-events. With an eye on the present, Andanças proposes reviving social habits of experiencing music by taking up the practice of popular dance, through multiple approaches to traditional Portuguese and world dances, with a view to the recovery of musical traditions and choreographies, merging them with contemporary elements. At Andanças you can learn more than fifty different dance styles: this is the result of the synergies generated among citizens of the world, eager to share knowledge. From Portuguese, African, American and European dances: Hungarian, Balkan, Basque, Gypsy, Baltic, Belgian, Poitou, Italian, Galician, Catalan, Mediterranean, etc. In addition to nurturing curiosity for diversity, Andanças also strives to remind us that popular music is (also) a synonym of identity which must be safeguarded.

The third strategy suggests "theming" as a regional regeneration driver and it involves spaces that seek to differentiate their attributes, focusing on specific themes such as culture, arts or entertainment, marketing them in a diversified way (Law, 1992; Swarbrooke, 1999, 2000; McCarthy, 2002). For example, in Portugal the topic of culture was highlighted with Guimarães Capital of Culture in $2012^{17}$ or in different sectors of activity such as wine (Reguengos de Monsaraz as European Capital of Wine 2015 ${ }^{18}$ ) or in sport with Euro 2004, or Gondomar European City of Sports $2017^{19}$, or in history and heritage with the Medieval Fairs of Santa Maria da Feira, the Gualterianas Festivals in Guimarães, etc. As an example: grape harvesting in Quinta Nova Nossa Senhora do Carmo, ${ }^{20}$ where visitors can participate in the harvesting activity and grape treading.

The fourth strategy is "heritage (re)valuation", whereby regions try to "restructure themselves by re-discovering their specially constructed cultural heritage" (Richards \& Wilson, 2006b), proposing new uses and purposes for it. Pousadas de Portugal, a government initiative by António Ferro, with the publication of Law 31.259 of 1st May 1941, is a good example of this. The Pousada de Elvas, in Alentejo, was the first to be inaugurated in 1942. In the following decade, the concept of 'historical inn' was developed, using historical buildings such as palaces, convents or castles (some in ruins), which were converted into hotel units, preserving their original cultural value. Currently there are 37 inns: 2 in the Azores, 10 in the Alentejo, 3 in the Algarve, 6 in the Central region, 6 in the region of Lisbon and Setúbal Peninsula and 10 in the North. They were distinguished in 1995 with the annual award of the American Society of Travel Agents and the Smithsonian Foundation as "a world institution with highly prominent role in the defence of cultural heritage and the environment for tourism purposes."

\footnotetext{
${ }^{16} \mathrm{At}$ http://www.andancas.net/2017/pt/

${ }^{17} \mathrm{At}$ http://www.eurocid.pt/pls/wsd/wsdwcoto.detalhe?p_cot_id=7600\#lista

${ }^{18}$ At http://www.recevin.net/?lng=po

${ }^{19} \mathrm{At}$ http://ced2017.cm-gondomar.pt/

${ }^{20}$ At http://www.viajecomigo.com/2013/09/16/douro-quinta-nova/
} 
The relationship between cultural and creative tourism and the main forms of development, as well as their relationship with the different types of tourist experiences, can be found in several destinations. Nationally we can find references in Alto Minho, Guimarães, Óbidos, Santa Maria da Feira and others. However, Portugal still does not have a city nominated for this network.

\section{Conclusion and development outlook}

Globalisation of the economy and the development of information and communication technologies have contributed significantly to the universalization of tourism as a truly global economic activity. According to UNESCO, creative tourism is considered a new generation of cultural tourism aimed at the interaction between various activities, such as the traditional cultural industries, the experiences related to the intangible universe of the arts, traditions, local culture, heritage preservation and activities arising from new technologies.

The difference between cultural and creative tourism is that "creative" tourists participate in an activity when they visit a destination, whereas cultural tourists have cultural experiences, which bring them closer to the inhabitants of the places which they visit.

Portugal is a tourist destination with a vast and rich cultural heritage, but a geographical area marked by the abandonment of a significant part of its territory and by the devaluation of its material and symbolic capital in low-population density areas. This low-population density area can be seen as an opportunity for social actors to meet (collective actions of social construction focused on solving problems) and for the coordination of creative tourism strategies with local development (creation of a unique tourism offer that values endogenous products), aiming at strengthening regional cultural identity.

According to Brunet (1990: 224), social relationships between the local actors in the area give rise to a sense of belonging to the constructed identity, creating bonds of solidarity between them.

When observing the potential of these areas, Sabourin (2002) called them local attributes or specific assets, considered as supply factors: creative industries, global cultural diversity, singular cultural supplies, hospitality, local tourist infrastructures, cultural tourism resources and other types of tourism.

Jollivet and Pavé (2000) consider that a region has the power to be manifested permanently via collective memory and social relations which are formed by local and external interactions, considered as Demand Factors, including: participation in Culture, Creativity, Innovation, Cultural Heritage Preservation, Authenticity, Human Interaction, Cultural Immersion and Cultural Tourism.

By defining creative tourism as that which "gives visitors the opportunity to develop their creative potential through active participation in courses and learning experiences that are characteristic of the holiday destination where they are held" Richards and Raymond (2000: 18) included it in the "experience economy" (Pine \& Gilmore, 1999), where value is centred on the experiences and emotions created for consumers (Prahalad \& Ramaswamy, 2004). 
Therefore, combining demand factors and supply factors gives rise to a new competitive environment in the market for creative tourism products and services. According to Salvado, Ferreira and Costa (2014: 42), the rationale behind the creation of value is no longer centred solely on the "value chain" (within the company) but it also absorbs input from the "constelations of value" from outside the company. The concept of "constellation of value" as Prahalad and Ramaswamy (2004) and Castells (1999) see it, focuses on the client and is based on the idea of supply (which involves a unique value or unique experience), in which different actors interact and contribute to the process of creating value.

Creative products/services have tangible benefits (Cultural Capital, Target Market Expansion, Innovation, Cultural Heritage Preservation, Sustainability, Job Creation, Brand Visibility and Exports) and intangible benefits (Identity and uniqueness of the places, Shared Capital, Preservation of cultural values, Preservation of cultural heritage, Cultural exchange, Diversification of local culture, Preservation of moral and spiritual values, Sense of pride and belonging) which generate value. Thus, in order to produce value, the solution will be to leverage areas' endogenous resources and core activities, using the talents of internal and external partners in the region. The rationale is to acquire innovative ideas and solutions from internal sources (communities) and from external information sources, through strategies of co-participation between stakeholders. Thus, a new value proposition will be made available to interested client segments. In this context Brandenburger and Nalebuff (1996) reinforce the importance of analysing and questioning the dichotomy between competition and cooperation within ecosystems. The coopetition strategy, in which businesses simultaneously cooperate and compete (Nalebuff \& Brandenburger, 1996), allows for complex relationships between the various partners. If this type of strategy is implemented in cultural and creative tourism, the results can generate a strong increase in local businesses, as well as the prosperity of the indigenous communities and, consequently, regional development.

\section{References}

Ackoff, R. L. (1981). Creating the corporate future: Plan or be planned for. New York: John Wiley \& Sons.

Ali, F., Ryu, K. \& Hussain, K.v (2016). Influence of experiences on memories, satisfaction and behavioral intentions: A study of creative tourism. Journal of Travel \& Tourism Marketing, 33(1), 85-100. doi: $10.1080 / 10548408.2015 .1038418$

Alvarez, M. D. (2010). Creative cities and cultural spaces: New perspectives for city tourism. International Journal of Culture, Tourism and Hospitality Research, 4(3), 171-175. doi: 10.1108/17506181011067565

Blapp, M. (2015). Creative tourism in Bali's rural communities. Examination of the current offer and advice on future product development (unpublished master's thesis). Breda University of Applied Sciences, Netherlands.

Boley, H. \& Chang, E. (2007). Digital ecosystems: Principles and semantics. In IEEE International Conference on Digital Ecosystems and Technologies (pp. 397-403). Ottawa, Canada: National Research Council Canada. doi: 10.1109/DEST.2007.372005

Booyens, I. \& Rogerson, C.M. (2015). Creative tourism in Cape Town: An innovation perspective. Urban Forum, 26(4), 405-424. doi: 10.1007/s12132-015-9251-y 
Brandenburger, A. \& Nalebuff, B. (1996). Coopetition. A revolutionary mindset that combines competition and cooperation. The game theory strategy that's changing the game of business. Nova York: Doubleday.

Bruin, A. \& Jelinčić, D.A. (2016). Toward extending creative tourism: Participatory experience tourism. Tourism Review, 71(1), 57-66. doi: 10.1108/TR-05-2015-0018

Brunet, R. (1990). Le territoire dans les turbulences. Paris: Reclus.

Castells, M. (1999). A sociedade em rede. São Paulo: Paz e Terra.

Chang, L. L., Backman, K.F. \& Huang, Y.C. (2014). Creative tourism: A preliminary examination of creative tourists' motivation, experience, perceived value and revisit intention. International Journal of Culture, Tourism and Hospitality Research, 8(4), 401-419. doi:10.1108/IJCTHR-04-20140032

Choay, F. (2006). A alegoria do património. Lisboa: Edições 70

Chronis, A. (2012). Tourists as story-builders: Narrative construction at a heritage museum. Journal of Travel \& Tourism Marketing, 29(5), 444-459. doi: 10.1080/10548408.2012.691395

Cole, S. T. \& Chancellor, H.C. (2009). Examining the festival attributes that impact visitor experience, satisfaction and revisit intention. Journal of Vacation Marketing, 15(4), 323-333.

Daniel, R. (2014). Building the northern Australia vision through creative industries: The case of Cairns in far north Queensland. Creative Industries Journal, 7(2), 134-147. doi: 10.1080/17510694.2014.961699

Deliberação da CIC [Comissão Interministerial de Coordenação do Acordo de Parceria] Portugal 2020 Retrieved from https://poseur.portugal2020.pt/media/37819/delibera\%C3\%A7\%C3\%A30_cic_pt2020_01072015 _territorios_baixa_densidade.pdf

Della Lucia, M., Trunfio, M. \& Go, F. M. (2016). Heritage and urban regeneration: Towards creative tourism. In Bellini, N. \& Pasquinelli, C. (Eds.), Tourism in the city: Towards an integrative agenda on urban tourism (pp. 179-191). New York: Springer.

Duxbury, N. (2019). Creative tourism in small cities and rural areas: Lessons from the creatour project, Portugal. TISC - Tourism International Scientific Conference Vrnjačka Banja (pp.64-81). Vrnjačka Banja: Faculty of Hotel Management and Tourism in Vrnjačka Banja, University of Kragujevac.

Duxbury, N., Silva, S. \& Castro, T. V. (2019). Creative tourism development in small cities and rural areas in Portugal: Insights from start-up activities. Creating and Managing Experiences. In D. A. Jelincic and Y. Mansfeld (Eds.), Creating and Managing Experiences in Cultural Tourism. Singapore: World Scientific Publishing.

ENEI [Estratégia Nacional Especialização Inteligente]. Retrieved from https://www.ani.pt/media/5238/enei-2014.pdf

European Commissioner for Regional Policy. Regional innovation ecosystems Retrieved from https://ec.europa.eu/regional_policy/en/atlas/portugal/ https://op.europa.eu/en/publication-detail/-/publication/6a43bcbb-85a9-43fc-afaz$\mathrm{db} 58 \mathrm{c} 42 \mathrm{f} 4730$

Evans, G. (2003). Hard-branding the cultural city-from Prado to Prada. International Journal of Urban and Regional Research, 27(2), 417-440. doi: 10.1111/1468-2427.00455

Evans, G. (2005). Creative spaces: Strategies for creative cities. In J. Swarbrooke, M. Smith and L. Onderwater (Eds), Tourism, Creativity and Development: ATLAS Reflections 2005 (pp.7-10). Arnhem: Association for Tourism and Leisure Education. 
Fernandes, C. \& Rachão, S. (2014). Reinventing tourism at a traditional cultural tourism destination: A case study of Viana do Castelo (Portugal). International Journal of Business and Globalisation, 12(3), 281-296. doi: 10.1504/IJBG.2014.060213

Fortuna, C. (2012). Património, turismo e emoção. Revista Crítica de Ciências Sociais, 97, 23-40. doi: $10.4000 /$ rccs. 4898

Garcia, B. (2004). Urban regeneration, arts programming and major events. International Journal of Cultural Policy, 10, 103-118. doi: 10.1080/1028663042000212355

Gee, C. \& Fayos-Solá, E. (1997). International tourism: A global perspective. Madrid: World Tourism Organization Publications. ISBN: 92-844-0231-X

Goeldner, R. \& Ritchie, B. (2006). Tourism: Principles, practices, philosophies. Hoboken, New Jersey: John Wiley \& Sons.

Gülüm, E. (2015). The relationship between creative tourism and folk culture and the popularization of locality. Milli Folklor, 105, 87-98

Harrington, D.M. (1999). Conditions and setting/environment. In R. Steven Pritzker (Ed.), Encyclopedia of creativity (pp.323-340) (Vol I). San Diego: Academic Press.

Hill, M. \& Hill, A. (2000). Investigação por questionário. Lisboa: Edições Sílabo.

Hingtgen, N., Kline, C., Fernandes, L. \& McGehee, N. G. (2015). Cuba in transition: Tourism industry perceptions of entrepreneurial change. Tourism Management, 50, 184-193. doi: 10.1016/j.tourman.2015.01.033

Hudson, S. \& Ritchie, J. R. B. (2009). Branding a memorable destination experience. The case of 'Brand Canada. International Journal of Tourism Research, 11(2), 217-228. doi: 10.1002/jtr.720

Hung, W.-L., Lee, Y.-J. \& Huang, P.-H. (2016). Creative experiences, memorability and revisit intention in creative tourism. Current Issues in Tourism, 19(8), 763-770. doi: 10.1080/13683500.2013.877422

Ihamäki, P. (2012). Geocachers: The creative tourism experience. Journal of Hospitality and Tourism Technology, 3(3), 152-175. doi: 10.1108/17579881211264468

Jollivet, M. \& Pavé, A. (2000). O meio ambiente: questões e perspectivas para a pesquisa. In: Vieira, P.F. \& Weber, J. (Orgs.), Gestão de recursos naturais renováveis e desenvolvimento (pp. 115146). Novos desafios para a pesquisa ambiental. São Paulo: Cortez.

Koudelková, P. (2017). Marketing communication of SMEs acting in creative tourism. In Alžbeta Királ'ová (Ed.) Driving tourism through creative destinations and activities (pp. 94-115). Hershey, Pennsylvania: IGI Global.

Landry, C. \& Bianchini, F. (1995). The creative city. London: Demos.

Law, C.M. (1992). Urban tourism and its contribution to economic regeneration. Urban Studies, 29(3/4), 599-618. doi: 10.1080/00420989220080581

Leiper, N. (1979). The framework of tourism: Towards a definition of tourism, tourist, and the tourist industry. Annals of Tourism Research, 6(4),390-407. doi: 10.1016/0160-7383(79)90003-3

Lindroth, K., Ritalahti, J. \& Soisalon-Soininen, T. (2007). Creative tourism in destination development. Tourism Review 62(3/4), 53-58. doi: 10.1108/16605370780000322

Markwick, M. (2017). Valletta ECoC 2018 and cultural tourism development. Journal of Tourism and Cultural Change, 16(3), 286-308. doi: 10.1080/14766825.2017.1293674

McCarthy, J. (2002). Entertainment-led regeneration: The case of Detroit. Cities, 19(2), 105-111. doi: $10.1016 /$ S0264-2751(02)00005-7 
McCormack, R. (2011). Digital ecosystems: A framework for online business, in Gretzel, U., Werthner, H., Koo, C. and Lamsfus, C. (2015). Conceptual foundations for understanding smart tourism ecosystems. Computers in Human Behavior, 50 (2015) 558-563, doi.org/10.1016/j.chb.2015.03.043

Messina, S.G.M., Gega, B.K. \& Pulido-Fernández, J.I. (2017). Policies and skills for creative tourism in emerging destinations of the Adriatic: Istria, Apulia, and Albania. Driving Tourism through Creative Destinations and Activities, 138-164.doi: 10.4018/978-1-5225-2016-0.choo7.

Mill, R. C. \& Morrison, A. M. (2002). The tourism system, Kendall. Dubuque, lowa: Hunt

Montalto, V., Moura, C., Langedijk, S. \& Saisana, M. (2017). The cultural and creative cities monitor. Luxembourg: Publications Office of the European Union.

Moore, J. (1993). Predators and prey: A new ecology of competition. Harvard Business Review, 71(3), 75-86.

Ngamsirijit, W. (2014). Value creation in creative tourism: Cocreation through data mining. International Journal of Intelligent Enterprise, 2(2-3), 255-276. doi: 10.1504/IJIE.2014.066676

Ngamsirijit, W. (2015). Demand responsive transportation for creative tourism logistics planning. International Journal of Intelligent Enterprise, 3(1), 38-53. doi: 10.1504/IJIE.2015.073446

Ohridska-Olson, R. \& Stanislav Ivanov (2010). The creative tourism business model. Cultural Realms (Rossitza OhridskaOlson's blog about the business of cultural tourism). Retrieved from https://culturalrealms.typepad.com/files/creativetourismbm_article_1_Ir.pdf

Pine, B. J. II. \& Gilmore H. J. (1999). The experience economy: Work is theatre and every business a stage. Boston, MA: Harvard Business School Press.

Poon, A. (1993). Tourism, technology and competitive strategies. Wallingford: CAB International.

Prahalad, C. K. \& Ramaswamy, V. (2004). The future of competition: Cocreating unique value with customers. Boston: Harvard Business School Press.

Prentice, R. (2001). Experiential cultural tourism: Museums \& the marketing of the new romanticism of evoked authenticity. Museum Management and Curatorship, 19(1), 5-26. doi: $10.1080 / 09647770100201901$

Rabazauskaitè, V. (2015). Revitalisation of public spaces in the context of creative tourism. Creativity Studies, 8(2), 124-133. doi: 10.3846/23450479.2015.1053543

Regulation (EU) $N^{\circ} 1295 / 2013$ of the European Parliament and of the Council (2013). Official Journal of the European Union L 347/221.

Reisinger, Y \& Steiner, C. J. (2006). Reconceptualizing object authenticity. Annals of Tourism Research, 33(1), 65-86. doi: 10.1016/j.annals.2005.04.003

Richards, G. \& Raymond, C. (2000). Creative tourism. Atlas News, 23, 16-20.

Richards, G. \& Wilson, J. (2006a). Developing creativity in tourist experiences: A solution to the serial reproduction of culture? Tourism Management, 27(6), 1209-1223. doi: 10.1016/j.tourman.2005.06.002

Richards, G. \& Wilson, J. (2006b). Developing creativity in tourist experiences: A solution to the serial reproduction of culture. Tourism Management, 27(6), 1209-1233. doi: 10.1016/j.tourman.2005.06.002

Richards, G. \& Wilson, J. (2006C). Tourism, creativity and development. Unpublished paper.

Richards, G. (2001). Cultural attractions and European tourism. CAB International, Wallingford. 
Richards, G. (2005). Creativity: A new strategic resource for tourism. In J. Swarbrooke, Smith J., Smith, M. and Onderwater, L. (Eds). Tourism, creativity and development: ATLAS reflections 2005 (pp. 11-12). Association for Tourism and Leisure Education, Arnhem.

Richards, G. (2014). Creativity and tourism in the city. Current Issues in Tourism, 17(2), 119-144. doi: 10.1080/13683500.2013.783794

Richards, G. (2011). Creativity and tourism: The state of the art. Annals of Tourism Research, 38(4), October, 1225-1253. doi.org/10.1016/j.annals.2011.07.008

Riegl, A. ([1903] 1984). Le culte moderne des monuments: Son essence et sa genèse. Paris: Éditions du Seuil.

Ritchie, J. R. B. \& Hudson, S. (2009). Understanding and meeting the challenges of consumer/tourist experience research. International Journal of Tourism Research, 11(2), 111-126. doi: 10.1002/jtr.721

Saayman, M. \& van der Merwe, A. (2014). Factors determining visitors' memorable wine-tasting experience at wineries. Anatolia: An International Journal of Tourism and Hospitality Research, 26(3), 372-383. doi: 10.1080/13032917.2014.968793

Sabourin, E. (2002). Desenvolvimento rural e abordagem territorial. Conceitos, estratégias e atores. In: Sabourin, E. and Teixeira, O. A. (Ed.) Planeamento e desenvolvimento dos territórios rurais. Conceitos, controvérsias e experiências (pp. 21-27). Brasília: EMBRAPA.

Salmna, D. \& Uygur, D. (2010). Creative tourism and emotional labor: An investigatory model of possible interactions. International Journal of Culture, Tourism and Hospitality Research, 4(3), 186-197. doi: 10.1108/17506181011067583

Salvado, J., Ferreira, A. \& Costa, C. (2014). Cocriação de valor: Uma perspetiva das agências de viagens independentes. Revista Turismo \& Desenvolvimento, 21/22, 35-50.

Shandwick, W. (2015). Innovation trends report: Networked smart cities part one in our ongoing series on macro trends shaping global society. Retrieved from http://www.webershandwick.com/uploads/news/files/WS-Networked-Smart-CitiesReport.pdf

Smith, M. (2005). Introduction. In J. Swarbrooke, M. Smith, and L. Onderwater, (Eds), Tourism, Creativity and Development: ATLAS Reflections 2005 (pp. 3-6). Arnhem: Association for Tourism and Leisure Education.

Sofield, T., Guia, J. \& Specht, J. (2017). Organic 'folkloric' community driven place-making and tourism. Tourism Management, 61, 1-22. doi: 10.1016/j.tourman.2017.01.002

Stamboulis, Y. \& Skayannis, P. (2003). Innovation strategies and technology for experience-based tourism. Tourism Management, 24(1), 35-43. doi: 10.1016/S0261-5177(02)00047-X

Štefko, R.\& Mudrík, M. (2016). Using social networks to create and share experiences in creative tourism. Driving Tourism through Creative Destinations and Activities, 260-277.

Steiner, C. J. \& Reisinger, Y. (2006). Understanding existential authenticity. Annals of Tourism Research, 33(2), 299-318. doi: 10.1016/j.annals.2005.08.002

Suárez, J.A.G. \& Fernández, J.I.P. (2015). Creacity, a proposal for an index to measure the tourist creativity. Application on three urban cultural destinations in Spain. Revista de Estudios Regionales, 103, 69-108.

Swarbrooke, J. (1999). Urban areas. In J. Swarbrooke, Sustainable Tourism Management (pp. 172-182). CABI Publishing, Wallingford.

Swarbrooke, J. (2000). Tourism, economic development and urban regeneration: A critical evaluation. In M. Robinson, R. Sharpley, N. Evans, P. Long, and J. Swarbrooke, (Eds), Developments in 
Urban and Rural Tourism, Centre for Travel and Tourism (pp. 269-285). Sheffield Hallam University and University of Northumbria, Sunderland.

Tan, S.-K., Kung, S.-F., Luh, D.-B. (2013). A model of 'creative experience' in creative tourism. Annals of Tourism Research, 41, 153-174. doi: 10.1016/j.annals.2012.12.002

Tan, S.-K., Luh, D.-B., Kung, S.-F. (2014). A taxonomy of creative tourists in creative tourism. Tourism Management, 42, 248-259. doi: 10.1016/j.tourman.2013.11.008

Tan, S.-K., Tan, S.-H., Luh, D.-B., Kung, S.-F. (2016). Understanding tourist perspectives in creative tourism. Current Issues in Tourism, 19(10), 981-987. doi: 10.1080/13683500.2015.1008427

Tansley, A. G. (1935). The use and abuse of vegetational concepts and terms. Functional Ecology, 16(3), 284-307. doi: 10.2307/1930070.

TP [Turismo de Portugal] (2013). Plano Estratégico para o Turismo. Lisgráfica, Impressão e Artes Gráficas, S.A. Lisboa.

TP [Turismo de Portugal] (2016). Turismo 2020: Cinco princípios para uma ambição. Retrieved from https://www.historico.portugal.gov.pt/media/15123712/20150805-turismo-2020.pdf

UNCTAD [United Nations Conference on Trade dnd Development] (2015). Creative Economy outlook and country profiles: Trends in international trade in creative industries. New York: United Nations.

UNESCO [United Nations Educational, Scientific and Cultural Organization] (2006). Towards Sustainable Strategies for Creative Tourism. Discussion Report of the Planning Meeting for 2008 International Conference on Creative Tourism, Santa Fe, New Mexico, U.S.A., October 25-27.

Vargo, S. \& Lusch, R. (2008). Service-dominant logic: Continuing the evolution. Journal of the Academy of Marketing Science, 36(1), 1-10. doi: 10.1007/s11747-007-0069-6

Wattanacharoensil, W. \& Sakdiyakorn, M. (2016). The potential of floating markets for creative tourism: A Study in Nakhon Pathom Province, Thailand. Asia Pacific Journal of Tourism Research, 21, S3-S29. doi: 10.1080/10941665.2014.998250

Wattanacharoensil, W. \& Schuckert, M. (2016). Reviewing Thailand's master plans and policies: Implications for creative tourism? Current Issues in Tourism, 19(10), 1045- 1070. doi: 10.1080/13683500.2014.882295

Whiting, J. \& Hannam, K. (2014). Journeys of inspiration: Working artists' reflections on tourism. Annals of Tourism Research, 49, 65-75. doi: 10.1016/j.annals.2014.08.007

The research, production and publication of this article was carried out under the European funding programme FEDER/PT2020 and with national funding by the Fundação para a Ciência e Tecnologia (FCT) - UID/HIS/00057/2013 - POCI-01-0145-FEDER-007702 project - CIDEHUS.

Josefina SALVAdo is a Post-Doctoral Grantee (BI_POS-DOC_CIDEHUS _TURISMO), under the scope of CIDEHUS - Centro Interdisciplinar de História, Culturas e Sociedades da Universidade de Évora UID/HIS/00057/2013 (POCl-01-0145-FEDER007702). Institutional address: Centro Interdisciplinar de História, Culturas e Sociedades, Universidade de Évora, Largo dos Colegiais, 2, 7000 Évora, Portugal. ORCID http://orcid.org/0000-0003-0351-4544

ANA MARIA FERREIRA is a member of CIDHEUS (Centro Interdisciplinar de História, Culturas e Sociedades) research member in Universidade de Évora. Institutional address: Centro Interdisciplinar de História, Culturas e Sociedades, Universidade de Évora, Largo dos Colegiais, 2, 7000 Évora, Portugal. 
JAIME SERRA is a teacher and a member of CIDHEUS (Centro Interdisciplinar de História, Culturas e Sociedades) research member in Universidade de Évora. Institutional address: Centro Interdisciplinar de História, Culturas e Sociedades, Universidade de Évora, Largo dos Colegiais, 2, 7000 Évora, Portugal.

NOÉMI MARUJO is is a teacher and a member of CIDHEUS (Centro Interdisciplinar de História, Culturas e Sociedades) research member in Universidade de Évora. Institutional address: Centro Interdisciplinar de História, Culturas e Sociedades, Universidade de Évora, Largo dos Colegiais, 2, 7000 Évora, Portugal.

Submetido em 27 de janeiro de 2020

Aceite em 12 de maio de 2020 